\title{
Coalescence of oil droplets in microchannels under brine flow
}

\section{Wang, Tian; Andersen, Simon Ivar; Shapiro, Alexander}

Publication date:

2021

Document Version

Publisher's PDF, also known as Version of record

Link back to DTU Orbit

Citation (APA):

Wang, T., Andersen, S. I., \& Shapiro, A. (2021). Coalescence of oil droplets in microchannels under brine flow. Abstract from DHRTC Technology Conference 2021 , Kolding, Denmark.

\section{General rights}

Copyright and moral rights for the publications made accessible in the public portal are retained by the authors and/or other copyright owners and it is a condition of accessing publications that users recognise and abide by the legal requirements associated with these rights.

- Users may download and print one copy of any publication from the public portal for the purpose of private study or research.

- You may not further distribute the material or use it for any profit-making activity or commercial gain

- You may freely distribute the URL identifying the publication in the public portal

If you believe that this document breaches copyright please contact us providing details, and we will remove access to the work immediately and investigate your claim. 


\section{Danish Hydrocarbon Research and Technology Centre Technology Conference 2021}

\section{Coalescence of oil droplets in microchannels under brine flow}

\section{Tian Wang, Simon Ivar Andersen, Alexander Shapiro}

We use microfluidics technique to study the coalescence of model oil droplets in microchannels. Different stages of the coalescence: convergence of the droplets and liquid film drainage, collision, interfacial film rupture, and merging are captured by high-speed imaging. The coalescence time is studied, defined as the merging time for the droplets after physical contact. Adding salts into the water phase may slow down the coalescence process. Cations $\mathrm{Na}^{+}, \mathrm{Ca}^{2+}$ and $\mathrm{Mg}^{2+}$ do not significantly affect the coalescence time, while the presence of the anion $\mathrm{SO}_{4}{ }^{2-}$ produces much longer times than of $\mathrm{Cl}^{-}$. The presence of a surface-active component, stearic acid, increases the coalescence time, in a clear correlation with the interfacial tension. At higher $\mathrm{pH}$ stearic acid is deprotonated into stearate; correspondingly, the interfacial tension decreases further and the electrostatic repulsion of the head groups of fatty acids increases. The interface between droplets and water is thereby stabilized and the coalescence time increases. A pH value higher than the pKa of stearic acid induces highly stable plastic-like oil-water interfaces. We discuss the implications of our results on the applications in the petroleum industry concerning e.g. enhanced oil recovery under smart waterflooding.

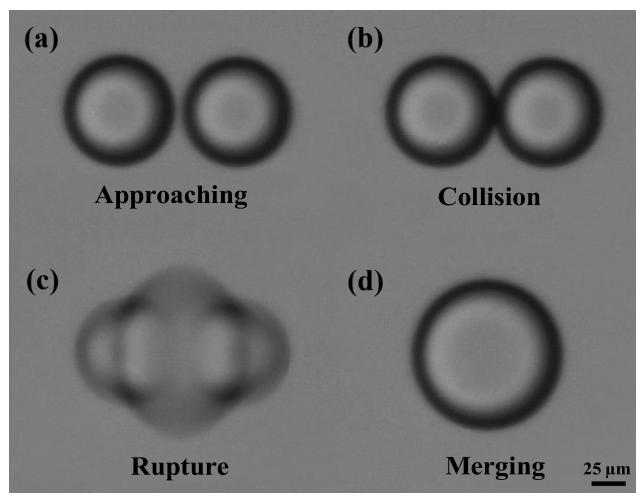

Figure 1. Four stages of the coalescence process: (a) approaching; (b) collision; (c) rupture of interfacial film and (d) merging. 